\title{
THE JOURNAL OF .
}
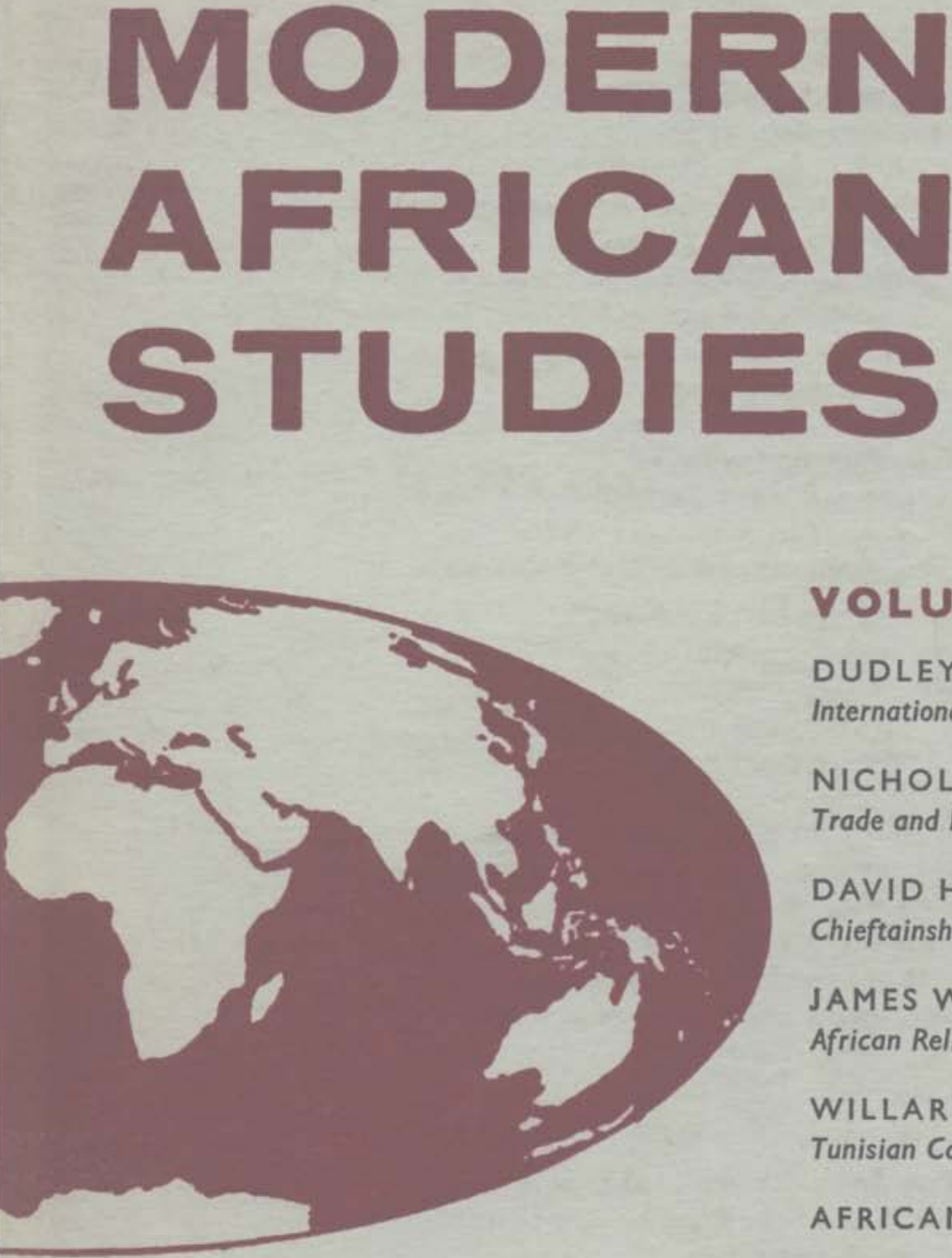

VOLUME 2 NUMBER 4

DUDLEY SEERS

International Aid: the Next Steps

NICHOLAS KALDOR

Trade and Economic Development

DAVID HAMMOND-TOOKE

Chieftainship in the Transkei

JAMES W. FERNANDEZ

African Religious Movements

WILLARD A. BELING

Tunisian Case Study of W.F.T.U.

AFRICANA REVIEWS

A QUARTERLY SURVEY OF POLITICS, ECONOMICS \& RELATED TOPICS IN CONTEMPORARY AFRICA EDITED BY DAVID \& HELEN KIMBLE 
Jamal Mонаммеd Aнмеd, Ministry of Foreign Affairs, Sudan Professor G. BALANdier, University of Paris

K. E. BERRILL, University of Cambridge

DR S. О. ВговакU, University of Ife, Nigeria

Professor P. J. BohanNan, Northwestern University, Evanston

Professor W. O. Brown, Boston University

Dr B. T. G. Ghidzero, U.N. Technical Assistance Board, Kenya

Professor J. S. Coleman, University of California, Los Angeles

Professor J. G. St Glair Drake, Roosevelt University, Chicago

THOMAS HODGKIN, University of Ghana

ЈонN Holmes, Canadian Institute of International Affairs, Toronto

Dr Arthur Lewis, Princeton University

Professor C. T. Leys, Makerere University College, Uganda

DR AB DOULAYE LY, I.F.A.N., University of Dakar

TAIB́ B SlIM, Tunisian Representative at the United Nations

Professor S. N. VARMA, University of Delhi

\section{CONTRIBUTIONS}

Contributions are invited from all over the world, and especially from scholars working in African universities. Articles written in languages other than English will be considered on their merits, and where necessary translation will be arranged. The average length suggested is 3,000 to 6,000 words, with occasional exceptions of up to I0,000 words. Notes on centres of African studies, research projects, and reports of recent conferences are also welcome.

All correspondence and contributions should be addressed to

The Editors, The Journal of Modern African Studies, at either University College, Dar es SalaAm, TANzania or University Press, Cambridge, England.

Each contributor will receive a copy of the number and 25 offprints of his article free of charge.

\section{SUBSCRIPTIONS}

Subscriptions (35s. net per annual volume of four parts, post free) are payable in advance, and may be sent to any bookseller, or to Cambridge University Press, Bentley House, 200 Euston Road, London, N.W.1. Subscribers in the U.S.A. should send their subscriptions ( $\$ 6.50$ per volume) to the Cambridge University Press, American Branch, 32 East 57th Street, New York, N.Y. 10022. 


\title{
AFRICA
}

\section{POLITICAL PARTIES AND NATIONAL INTEGRATION IN TROPICAL AFRICA}

Edited by James S. Coleman and Carl G. Rosberg, Jr.

The sixteen essays in this book focus attention on the role of political groups in the functioning and the development of the new African societies and the political systems of which they are a part.

$\$ 10.00$

\section{FEDERAL GOVERNMENT IN NIGERIA}

\section{by Eme O. Awa}

The first systematic treatment of the entire structure of Nigerian government and the actual working of that country's unique federal parliamentary system. Part One surveys the history of Nigerian political development. Part Two deals with the present governmental organization. Part Three treats regional governments. A final section is devoted to the unsolved problems of Nigerian federalism.

$\$ 8.00$

\section{POLITICAL AWAKENING IN THE CONGO by René Lemarchand}

An analysis of the broad range of circumstances and motivations that have conditioned the emergence of Congolese political groups. These circumstances are related to modern political developments with a view toward uncovering and explaining the basic tensions and discontinuities that have affected the growth of Congolese parties.

$\$ 7.95$

\section{THE CAMEROONS FROM MANDATE TO INDEPENDENCE}

\author{
by Victor $T$. Le Vine
}

The colonial experiences of the Cameroons make that country a subject of unique interest among the emerging nations of Africa. This analysis in depth of the process of nation-building affords a study in which the elements of that process can be distinguished with unusual clarity.

$\$ 7.50$

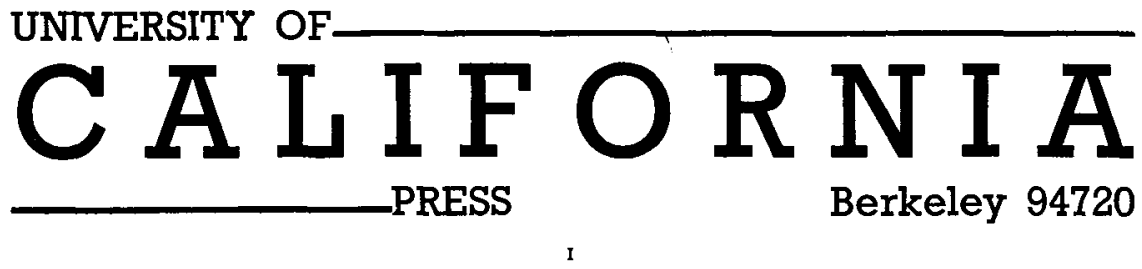




\section{The United States and the Italo-Ethiopian Crisis}

Brice Harris, Jr. This study analyzes the part played by the United States in the Italo-Ethiopian débâcle, discussing whether or not the lack of positive American cooperation was responsible for the failure of the League of Nations to restrain Mussolini.

\section{Trade Castles and Forts of West Africa}

A. W. Lawrence. A detailed description and history of nineteen forts that for over three centuries were the Western world's sole beachhead in tropical Africa. Illustrated with 96 pages of photographs and drawings, and 47 text figures of building plans.

$\$ 10.00$

Order from your bookstore, please

\section{STANFORD UNIVERSITY PRESS}

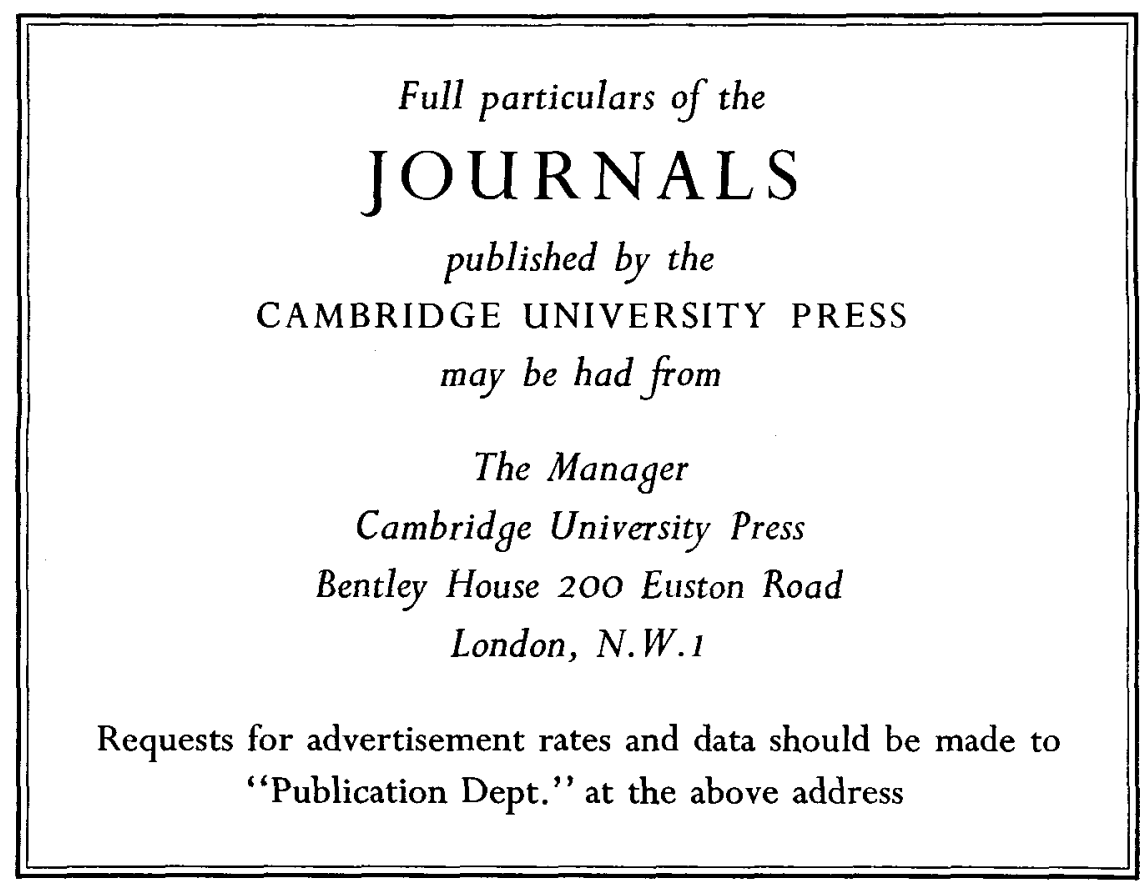




\section{AFRICA}

OR

DEATH!

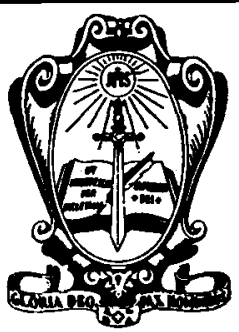

By Reverend A. G. Mondini F.S.C.J.

This fast-moving biography dramatically retells the events in the heroic life of a dedicated African missionary, Bishop Daniel Comboni, founder of the Verona Fathers and Sisters. 336 pages, illustrated with photographs, recount the feats of this zealous "St.

Francis Xavier of Central Africa," who never lessened in his love for souls on this vast continent.

Yes, you may now order directly from:

ST. PAUL EDITIONS, Daughters of St. Paul,

50 St. Paul's Avenue, Boston,

Massachusetts 02130, U.S.A.

Please send to me AFRICA OR DEATH!

cloth copy(ies) at $\$ 4.00$ each

paperback copy(ies) at $\$ 3.00$ each

Name

Address

City

State.$\ldots \ldots \ldots \ldots \ldots$ Zip Code .............

\section{The Maghreb Digest}

\section{North African Perspectives}

Designed to fill the gap in current area studies research on North Africa, the Maghreb Digest provides a monthly review of political, economic, and social reporting on the Maghreb countries of Algeria, Morocco, Tunisia and Libya. The review is based largely on a careful reading of the Arabic and French language periodicals of the Maghreb, supplemented by special reports.

Annual subscription rate: $\$ 12.00$ (12 issues)

Sample copies available upon request

The Middle East and North African Program School of International Relations

University of Southern California

Los Angeles, California, 90007

'The Digest . . . is a welcome aid to contemporary Maghreb studies. I recommend it highly.'-A. $\mathscr{f}$. Meyer, Associate Director, Center for Middle Eastern Studies, Harvard University.

\section{UNESCO: Selected Publications on Africa}

\section{Bibliography of African Hydrology}

Covers publications dealing with the water cycle in Africa, from precipitation to arrival in the sea or in underground aquifers, but excluding hydraulic engineering. This bibliography thus includes works on surface hydrology, precipitation, evaporation, infiltration and hydrogeology, as well as erosion with particular reference to solid transports.

32s. 6d. (33s. 4d.)

\section{Tropical Solls and Vegetation}

Proceedings of the Abidjan Symposium

Papers presented to the symposium: The role of the soil type as a determining ecological factor in the tropics; The influence of vegetation on soil organic matter, synthesis and decomposition of humic matter; Chemical analysis of run-off and percolating water; Systems of permanent exploitation of land with a combination of crops, animal husbandry, chemical fertilizers and organic manuring; Subtropical forests of Transcaucasia; Cerrados of Brazil. The publication contains illustrations, graphs and maps.

21s. 9d. (22s. 5d.)

\section{Science Teaching in the secondary Schools of Tropical Africa}

An analysis of the present position and of the needs of science education in the various States and Territories of Tropical Africa. Subjects covered include syllabuses, time-tables, and textbooks; laboratories and scientific equipment; recruitment, and preliminary and in-service training of science teachers; popularization of science. Contains diagrams. 11s. (11s. 6d.)

Prices in brackets include postage at inland rates

Send for a fully descriptive brochure on these and other selected titles on Africa to Her Majesty's Stationery Office, P6A (JMAS), Atlantic House, Holborn Viaduct, London, E.C.I

\section{HMSO}

The publications can be purchased from the Government Bookshops in London, Edinburgh, Manchester, Birmingham, Cardiff, Bristol and Belfast, or through any bookseller. UNESCO have agents in most countries for the sale of their publications. In case of difficulty please write to Documents \& Publications Service, UNESCO, place de Fontenoy, Paris-7e, France 


\section{Huggins of Rhodesia \\ LEWIS H. GANN and M. GELFAND}

'A most timely, as well as an intensely interesting, biography of Godfrey Huggins, first Viscount of Malvern'. Yorkshire Post

'a work that is of great value to politicians today and for historians as a source book in years to come.' DESMOND DONNELLY, in Western Mail

'ought certainly to be read by any student of African politics.' Financial Times

Illustrated $42 \mathrm{~s}$

\section{Britain and Nyasaland GRIFF JONES}

'In this careful, well annotated and scholarly account of the history of Nyasaland and the policies pursued there by successive British Governments, he provides devastating ammunition for the charges made in the sub-title of the book - "a story of inattention, fitful care, political vacillation". For anyone seeking to understand the position of Nyasaland and its government, Mr Jones's work is most valuable. Well worth reading.' Times Literary Supplement

'a scholarly production of high order ... the reader's interest will be held from first to last. Being a book written from within the territory, it uncovers many facts hitherto unknown and its authenticated description of Nyasaland life before and after Livingstone's day are revealing.' African Affairs

\section{Africa's Freedom}

Some of the most thoughtful African leaders give their views on their countries' problems: how to finish the freeing of the continent, the forms of government most suitable for a newly independent country, the role of the trade unions, how to canalize nationalist energies into creative work, how to avoid public corruption, and above all how to unify an enormous and diverse continent, and give expression to the African personality. Unwin Book

Paper $5 s$

\section{Money and Finance in Africa ERIN E. JUCKER FLEETWOOD}

An attempt to describe the problems faced and solutions found by the monetary and financial authorities of Ghana, Morocco, Nigeria, the Rhodesias and Nyasaland, the Sudan and Tunisia, from the establishment of their central banks till 1962.

'a very broadly conceived examination of the part central banking has so far played, and should play in the future in giving substance to the 'right' of backward nations to develop into modern industrial societies.' Bankers' Magazine.

\section{ALLEN \& UNWIN}




\section{THE JOURNAL OF MODERN AFRICAN STUDIES}

\begin{tabular}{lllll}
\hline VOLUME 2 & DEGEMBER I 964 & NUMBER 4 \\
\hline
\end{tabular}

\section{ARTICLES}

INTERNATIONAL AID: THE NEXT STEPS

DUDLEY SEERS, Director-General of Economic Planning, Ministry of Overseas

Development, London

INTERNATIONAL TRADE AND ECONOMIC

DEVELOPMENT

NIGHOLAS KALDOR, Fellow of King's College, Cambridge

CHIEFTAINSHIP IN TRANSKEIAN POLITICAL

DEVELOPMENT

David ham mond-tooke, Professor of Social Anthropology and Head of the

Department of African Studies, Rhodes University, Grahamstown

AFRICAN RELIGIOUS MOVEMENTS--TYPES AND

DYNAMICS

Dr James w. Fe Rnandez, Associate Professor of Anthropology, Dartmouth

College, New Hampshire

W.F.T.U. AND DEGOLONISATION: A TUNISIAN CASE STUDY

D R Will a d D A. Be Ling, Area Program Coordinator, Middle East/North African

Program, School of International Relations, University of Southern California,

Los Angeles

REVIEW ARTICLE

THE OVERSEAS DEVELOPMENT INSTITUTE AND ITS PUBLICATIONS

MIGHAEL LEE, Lecturer in Government, University of Manchester

\section{AFRICANA}

The African Institute for Egonomic Development and Planning,

DAKAR MOGENS BOSERUP, The African Institute for Economic Development and Planning, Dakar

East Afrigan Studies Program, Syracuse Univerity DR FRED G. BUR KE, East African Studies Program, Syracuse University

Centre of West African Studies, University of Birmingham PROFESSOR JOH F F E, Centre of West African Studies, University of Birmingham

Conferenge of Speakers and Glerks of Parliaments of Eastern and Gentral Afrigan Territories in Nairobi

R. V. VA De f E L T, Commonwealth Parliamentary Association, London

International Congress on French-SPeaking Africa in Washington, D.C. DR William h. Lewis, Office of Research and Analysis for Africa, U.S. Department of State, Washington

Seminar on Afrigan Primary Production and Internatronal Trade in Edinburgh I AN G. STE WART, Department of Political Economy, University of Edinburgh

University of East Africa Conference on Public Poligy : II I. Problems OF Foreign Aid in Dar es Salaam KENNETH GHRISTOFAs, University College, London 
Recontre Internationale de Poìtes in Berlin RAJAT NEOGY, 'Transition', Kampala, Uganda

The Spegialised Commissions of the Organisation of Aprigan UNITY COLIN LEGUM, 'The Observer', London

\section{REVIEWS}

The Image of Africa: British ideas and action, $1780-1850$ by PHILIP D. CURTIN professor ASA BRIGGS, School of Social Studies, University of Sussex, Brighton

One-Party Government in the Ivory Coast by AR ISTIDE R. ZOL BE R G HE N Y BIE NE N, Department of Political Science, Makerere University College, Kampala

The New States of West Africa by Ken Post DR WIL I I M TORDOF F, Institute of Public Administration, The University College, Dar es Salaam

The New Liberia by Lawrence A. Marinelli

Tribe and Class in Monrovia by MERRAN FRAENKEL HENRY B. COLE, 'The Liberian Star', Monrovia

Israel and Africa by MordechaI E. KREININ AARON SEGAL, Nairobi

The Economics of the Developing Countries by HLA My INT D R R. H. GREEN, Department of Economics, University of Ghana, Legon

Development Administration: Concepts and Problems edited by I R ving SWe RdLOW

Technical Assistance in Public Administration Overseas by EDWARD W. WEIDNER D R H ADLE Y E. SMI T H, Institute of Public Administration, The University College, Dar es Salaam

Aid to Africa by I. M. D. LiTtLe

$$
\text { A. F. EWIng, U.N. Economic Commission for Africa, Addis Ababa }
$$

Africans on the Land by MONTAGUE YUdelmaN DR SELBY в. N G СОво, Department of Economics, University College of Rhodesia and $\mathcal{N}$ jasaland, Salisbury

The Place of Customary Law in the National Legal Systems of East Africa by WI L LIAM T WINING African Conference on Local Courts and Customary Law: Record of the Proceedings of the

Conference held in Dar es Salaam, 8-18 September 1963 Y AS H G HA , Faculty of Law, The University College, Dar es Salaam

Foyce Cary's Africa by M. M. MAноOD DR E L D R D JONES, Department of English, The University College of Sierra Leone, Freetoron

Les Ecrivains noirs de langue frangaise: naissance d'une littérature by LIL Y AN KESTELOOT PROFESSOR HASSAN EL NOUTY, Department of French, University of California, Los Angeles 